\title{
MANFAAT LANGSUNG TERUMBU KARANG DI DESA TUMBAK KABUPATEN MINAHASA TENGGARA
}

\section{(Direct Benefit Value of Coral Reefs in the Tumbak Village Southeast Minahasa Regency)}

\author{
Ingrid Sembiring ${ }^{1}$, Adnan Wantasen ${ }^{2}$, Edwin L.A. Ngangi ${ }^{2}$ \\ ${ }^{1}$ Program Pascasarjana, Universitas Sam Ratulangi, Manado, Sulawesi Utara. \\ ${ }^{2}$ Fakultas Perikanan dan Ilmu Kelautan Universitas Sam Ratulangi, Manado, Sulawesi Utara.
}

\begin{abstract}
Penangkapan ikan yang destruktif (menggunakan bom dan racun) dan pengambilan karang untuk dijadikan fondasi rumah menjadi isu dalam pengelolaan pesisir di Desa Tumbak. Tujuan penefítian ini adalah (1) Mengetahui nilai manfaat langsung terumbu karang sebagai tempat penangkapan ikantolepr masyarakat di Desa Tumbak; (2) Mengetahui nilai manfaat langsung terumbu karang sebagai bahan bangunan oleh masyarakat di Desa Tumbak; (3) Mengetahui total nilai pemanfaatan terumbukarang sebagai tempat penangkapan ikan dan sebagai bahan bangunan oleh masyarakat di Desa Tumbak. Niłai manfaat langsung terumbu karang untuk fondasi rumah diperoleh Rp6.177.600 per tahun dan nilai manfaat langsung terumbu karang untuk penangkapan ikan karang Rp4.860.000.000. Total nilai manfaat langsung dari kedua pemanfaatan ini yaitu: Rp4.866.177.600. Total nilai ini belum termasuk pemanfaatan dalam bentuk lain terhadap ekosistem terumbu karang. Pemanfaatan terumbu karang sebaga bahan bangunan terutama disebabkan oleh faktor biaya yang murah dan jarak yang dekat dengan pemukiman. Praktik pemanfaatan yang tidak berkelanjutan ini menyebabkan degradasi kondisi terumbu karang sehingga tutupan karang hidup berada dalam kategori rusak (sedang). Jika terjadi terus-menerus, hal ini dapat menghilangkan fungsi ekologis sebagai peredam ombak dan fungsi ekonomis sebagai sumber pangan.
\end{abstract}

\begin{abstract}
Kata kunci: Tumbak; nilai manfaat langsung; terumbu karang; ekoststem
The issues of destructive fishing practices (using of bombs and poisons) and the use of corals as construction building materials have become issues intcoasta management in Tumbak Village. The aims of this study are (1) to find out the value of the direct benefits of coral reefs as fishing ground to the communities in Tumbak village, (2) to find out the value of the direct benefits of coral reefs as building materials to the communities in Tumbak village; (3) to find out the total value of the use of coral reefs as a fishing ground and as a construction materials for to the communities in Tumbak village. The value of direct benefit of the coral reef for building foundation was Rp 6,177,600 per year and the value of direct

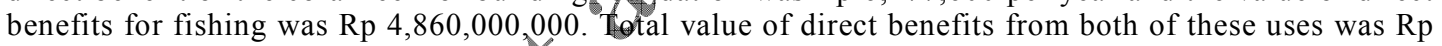
$4,866,177,600$. Total value did not includethe use of other forms of coral reef ecosystems. In conclusions, the use of coral reefs as a buildyng materials were mainly due to the low cost and the proximity to residential areas. Such category unsustainable practice has led to the degradation of coral reefs down to damaged category (medium category). If this happened continuously, the ecological function as wave
\end{abstract} protectors and economic fupctions as a source of food could be eliminated.

Keywords: Tumbak; direet benefit value; coral reefs; ecosystem.

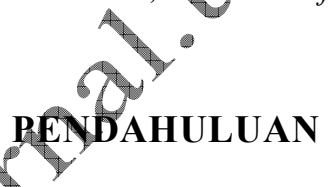

Berdasarkan sudut pandang sektor riil ekonomi pembangunan, baik upaya mengatasi krisis ekonomi maupun tujuan untuk mewujudkanbangsa yang maju dan makmur, pada dasarnya memerlukan pertumbuhan ekonomi secara berkesinambungan. Dalam tatanan ekonomi dunia dengan era globalisasi dan perdagangan bebas yang menjadi ciri dominan, pertumbuhan ekonomi secara berkelanjutan dari suatu bangsa hanya dapat diwujudkan jika bangsa tersebut dapat menciptakan sumber pertumbuhan baru dan memelihara atau meningkatkan efisiensi sumber pertumbuhan yang ada. Oleh karena itu tantangan paling mendasar bagi Indonesia ialah bagaimana membangkitkan perekonomian melalui penggalian sumber-sumber pertumbuhan ekonomi nasional secara efisien dan berkesinambungan. Salah satu sumber pertumbuhan yang diharapkan adalah sumber daya alam pesisir yang dapat meningkatkan kesejahteraan masyarakat di dalamnya serta terjaganya lingkungan dan sumber daya alam yang ada secara berkesinambungan (Bengen, 2002).

Dewasa ini kerusakan terumbu karang terutama di Indonesia meningkat secara pesat. Kerusakan ini menyebabkan meluasnya tekanan pada ekosistem terumbu karang alami. Hal ini akan mempengaruhi produktivitas alami dari 
perikanan sebagai sumber mata pencaharian terbesar dari masyarakat pesisir. Perikanan dan permasalahannya merupakan bagian yang penting dari ekosistem. Semakin beragamnya jenis terumbu karang yang ada maka semakin beraneka ragam pula jenis ikan yang hidup pada ekosistem tersebut. Praktik-praktik pengeboman ikan karang dan pengambilan karang serta aktivitas lainnya yang dilakukan di kawasan terumbu karang berpotensi besar mengancam kelestarian hidup ekosistem karang.

Desa Tumbak merupakan desa pesisir yang terletak di Kecamatan Pusomaen Kabupaten Minahasa Tenggara, Provinsi Sulawesi Utara, sekitar $100 \mathrm{~km}$ dari Kota Manado. Desa Tumbak mempunyai ekosistem sumber daya pesisir yang sangat penting yakni terumbu karang dan hutan bakau. Kedua ekosistem ini merupakan yang terluas di Kabupaten Minahasa Tenggara, luasan terumbu karang mencapai lebih dari 500 hektar dan hutan bakau mencapai 200 hektar. Kondisi ini menempatkan Desa Tumbak sebagai daerah yang penting untuk pengelolaan sumber daya pesisir dan untuk aktivitas ekonomi sehubungan dengan penangkapan ikan di Kabupaten Minahasa Tenggara. Aktivitas manusia yang merusak karang sudah jauh berkurang dalam beberapa tahun terakhir ini, namun demikian karang yang sudah terlanjur rusak memerlukan waktu bertahun-tahun untuk melakukan regenerasi.

Pengelolaan pesisir yang dilakukan oleh proyek pesisir (1998-1999) di daerah Tựmbak mengidentifikasi isu kerusakan terumbu karang yang aktual terjadi yakni penambangan terumbu karang dan penangkapan ikan yang lestruktif (bom dan racun). Merubah persepsi masyarakat terhadap lingkungan dan sumber daya pesisir khususnya terumbu karang kepada masyarakat yang secara langsung memanfatkan ekosistem ini khususnya para nelayan merupakan hal yang perlu dilakukan. Hal in dapat dicapai melalui pemberian informassi tèntang nilai ekonomi dan manfaat langsung tertmbu karang.

- Secara umum penelitian ini dilakukan untuk menjadi masukan neraca sumber daya alam terumbu karang di Desa Tumbak dan menilai manfaat langsung ekosistem terumbu karang yang dimanfaatkan oleh masyarakat sebagai tempat penangkapan ikan dan pemanfaatan karang sebagai bahan bangunan dalam hal ini fondasi rumah.

Berdasarkan permasalahan tersebut di atas penelitian ini dilakukan dengan tujuan untuk mengetahui nilai manfaat langsung terumbu karang sebagai tempat penangkapan ikan dan sebagai bahan bangunan oleh masyarakat di Desa Tumbak serta mengetahui total nilai dari kedua pemanfaatan tersebut.

\section{METODE PENELITIAN}

\section{Lokasi Penelitian}

Penelitian dilakukan di perairan Desa Tumbak Kabupaten Minahasa Tenggara selama 6 (enam bulan).

\section{Metode Penelitian}

Data yang dikumpulkan alam penelitian ini berupa data primer dan sekunder dan bersifat deskriptif kuantitatif. Pemilihan objek penelitian dilakukan secara sengaja dengan dasar pertimbangan bahwa di tokasi ini terumbu karangnya telah termanfaatkan.

Data primer dikumpulkan melalui pengamatan langsung de lapangan dan wawancara dengan aparat desa serta rumah tangga responden dengân menggunakan daftar pertanyaan yang telah disédiakan. Data primer yang dikumpulkan berupa data wawancara responden dan data ltfeform karang.

Data sekunder dikumpulkan dari pihak aŕn berupa laporan penelitian, laporan dari instansi terkait, serta laporan Lembaga Swadaya Masyarakat (Parizot, 2010 dan Proyek Pesisir, 1999) yang pernah melakukan penelitian sebelumnya. Data sekunder yang dikumpulkan berupa: luas terumbu karang yang tercakup dalam batasan lokasi penelitian, keadaan umum tempat penelitian, jumlah nelayan, rumah tangga nelayan, umum dan pembudidaya, kondisi rumah, data geografis, data demografi dan data lainnya.

Faktor-faktor sosial yang mempengaruhi permintaan rumah tangga dalam pemanfaatan secara langsung sumber daya terumbu karang untuk memenuhi kebutuhan hidupnya terutama umur kepala keluarga, tingkat pendidikan dan jumlah anggota keluarga. Faktor ekonomi yang mendorong terjadinya pemanfaatan secara langsung sumber daya yakni jumlah pendapatan per $\mathrm{KK}$, biaya per trip pengambilan karang dan biaya pembuatan fondasi rumah.

\section{Metode Pengumpulan Data}

Pengumpulan data tutupan karang dilakukan dengan menggunakan teknik transek garis pada 3 lokasi yang sama dengan pengambilan sampel kualitas air menggunakan peralatan 
scuba. Tiap lokasi diletakkan transek garis berukuran $50 \mathrm{~m}$ (3 transek garis) dengan jarak $5 \mathrm{~m}$ dengan posisi sejajar garis pantai dan mengikuti kontur. Pada setiap transek garis, setiap spesies karang diidentifikasi dan lifeform karang di catat pada data sheets. Selain itu keadaan terumbu karang sekitar lokasi difoto dengan menggunakan kamera bawah air.

\section{Metode Analisis Data}

Analisis persentase penutupan karang di duga melalui pendekatan persentase tutupan karang hidup di ekosistem terumbu karang. Data mengenai spesies dan lifeform selanjutnya diolah dengan menggunakan program Lifeform $\mathrm{Ca}$ tegory untuk memperoleh nilai. Persentase tutupan karang mengacu pada Kepmen Lingkungan Hidup no. 4, 2001 yaitu: kategori rusak/buruk $(0-24,9 \%)$ dan sedang $(25-49,9 \%)$; baik (50-74,9\%) dan baik sekali (75-100\%).

Pendekatan menghitung nilai manfaat langsung (direct use value) dari terumbu karang yakni kegiatan pengambilan karang untuk berbagai keperluan terutama bahan bangunan dan sebagai sumber pangan melalui penangkapan ikan, dengan rumus (Fauzi dan Anna, 2005):

dimana:

$$
\mathrm{ML}=\mathrm{ML}_{1}+\mathrm{ML}_{2} \quad \text { (dalam rupiah) }
$$

ML : manfaat Langsung;

$\mathrm{ML}_{1}$ : manfaat Langsung karang sebaga bahan bangunan/fondasi rumah.

$\mathrm{ML}_{2}$ : manfaat Langsung ikan hasil tangkapan di area terumbu karang

\section{HASIL DAN PEMBAHASAN}

\section{Kondisi Terumbu Karang}

Persentase tutupan terumbu karang hidup di perairan Tumbak yang diperoleh sebesar 31,8\%. Kepmen Lingkungan Hidup No. 4, 2001 tentang Kriteria BakuKerusakan Terumbu Karang pasal 2 ayat menyatakan bahwa kriteria baku kerusakan terumbu karang ditetapkan berdasarkan persentase fuas tutupan terumbu karang yang hidup. Dari persentase yang didapat, terumbu karang di lokasi penelitian termasuk dalam kategori rusak dengan golongan sedang, yakni di dalam kisaran $25 \%-49,9 \%$.

\section{Nilai Manfaat Langsung Terumbu Karang}

Manfaat langsung terumbu karang sebagai tempat penangkapan ikan karang yang dimaksud yaitu bahwa terumbu karang dianggap memberikan manfaat langsung kepada masyarakat sebagai sumber pangan dan memberikan penghasilan. Nilai ekonomis dari ekosistem terumbu karang sangat memegang peranan penting, terutama perikanan kecil nelayan-nelayan setempat untuk memenuhi kebutuhan hidupnya sehari-hari. Terumbu karang menjadi sumber mata pencaharian utama bagi nelayan. Sumber perikanan yang ditopang terumbu karang memiliki arti penting bagi masyarakat setempat yang pada umumnya masih memiliki alat tangkap tradisional.

Nelayan di Desa Tumbak méakukán kegiatan menangkap ikan untuk keperluan dijual di pasar dengan cara kelompok. Dalam satu perahu ada 4 nelayan yang ikut dan hasil penjualan ikan kemudian dibagi. Datam 1 minggu nelayan pergi menangkap ikan rata-rata 3 kali yang artinya 12 kali dalam sebulan dan 108 kali dalam setahun. Dengan asumsi bahwa di Desa Tumbak pada Búlarp Juli, Agustus dan Desember nelayan jayang menangkap ikan karena tiupan angin keneang pada bulan-bulan ini akibat cuaca buruk. Jadi hanya 9 bulan dalam 1 tahun yang dipakai nelayan untuk menangkap ikan. Alat tangkap perikanan yang dipakai antara lain hubate/funae, soma nyare, panah/jubi dengan menggunakan perahu pelang katinting, londe atau perahu dayung. Hasil tangkapan ikan karang seperti ikan ekor kuning, baronang, kerapu, kakap. Ikan-ikan tersebut merupakan ikan target dengan harga jual lebih mahal dan permintaannya banyak. Berat ikan hasil tangkapan per trip rata-rata adalah $30 \mathrm{~kg}$ yang berarti dalam setahun 1 kelompok nelayan mendapat $3.240 \mathrm{~kg}$ ikan. Harga ikan di pasar rata-rata Rp. $15.000 / \mathrm{kg}$ yang berarti penerimaan Rp.450.000/kelompok/ trip atau Rp.5.400.000/kelompok/bulan atau Rp. 48.600.000/kelompok/tahun. Jumlah nelayan per perahu adalah 4 orang. Diperoleh, manfaat langsung Rp.112.500/orang/trip; Rp.1.350.000/ orang/bulan; Rp.12.150.000/orang/tahun. Dari data potensi kelautan dan perikanan Desa Tumbak (2011) terdapat 400 nelayan kecil, diperoleh manfaat langsung penangkapan ikan sebesar Rp.4.860.000.000/desa/tahun. Penelitian lainnya menyebutkan bahwa estimasi tangkapan ikan karang per tahun oleh nelayan di Pulau Ternate adalah 4 ton per tahun dengan rata-rata $10-20 \mathrm{kali}$ menangkap ikan dengan sistem one day fishing (Dewi, 2006).

Manfaat langsung terumbu karang untuk konstruksi bangunan pesisir yang dimaksud yaitu bahwa terumbu karang dianggap memberikan 
manfaat langsung kepada masyarakat untuk digunakan sebagai bahan bangunan. Dengan hanya menggunakan perahu dengan jarak yang dekat di perairan sekitar dan biaya yang kecil, karang sebagai pengganti batu gunung atau batu kali sudah bisa diperoleh. Dibandingkan jikalau harus membeli, biayanya terhitung mahal dan memberatkan bagi masyarakat yang umumnya pendapatannya kecil. Terumbu karang mempunyai potensi di sektor perikanan, sub-sistem terumbu karang mempunyai manfaat lainnya salah satunya yakni sebagai bahan bangunan $(\mathrm{Su}-$ priharyono, 2004). Akan tetapi manfaat langsung terumbu karang sebagai bahan bangunan ini dapat dikategorikan sebagai manfaat yang tidak berkelanjutan.

Beberapa manfaat berkelanjutan yang awalnya mampu disediakan pada akhirnya tidak berkelanjutan karena laju pemanfaatannya yang berlebihan atau metode yang digunakan bersifat merusak (destruktif), contohnya penangkapan ikan menggunakan bom atau racun, aktivitas pengumpulan biota ornamental (kerang) yang pada awalnya hanya bertujuan sebagai hobi atau koleksi namun apabila sudah bersifat ekstraktif dan bertujuan untuk memenuhi permintaan pasar akhirnya berpotensi mengganggu kesesimbangan ekosistem alami terumbu karang. Contoh lain dengan dampak terbesar dan paling merusak yakni pembangunan pesisir menggunakan karang dengan mengambil secara terus-mécerus untuk memenuhi kebutuhan manusia (pemukiman untuk fondasi rumah, pelabuhan jalan, industri). Keperluan konstruksi pembangunan pesisir dan sarana yang ada di dafamenya menyumbang kerusakan terumbu karang karena penggunaan batu karang. Manfaa langsung terumbu karang dapat berkurang atau bahkan musnah apabila di wilayah pesisir terdapat aktivitas yang tidak ramah lingkungan. Contohnya, penelitian yang dilakukan Rembet et.al. (2011) menemukan bahwa struktur komunitas ikan target yang ekonomis penting tisa berubah atau berkurang tergantung padakondisi terumbu karang.

8 Berdasarkan kuesoner diperoleh bahwa masyarakat menggunakan karang sebagai fondasi rumah karena berbagai alasan dan yang terutama karena meringankan mereka dari segi dana. Hasil perhitungan terhadap pemanfaatan langsung terumbu karang sebagai fondasi rumah, diperoleh rata-rata kebutuhan batu per rumah tangga ialah $12,855 \mathrm{~m}^{3}\left(13 \mathrm{~m}^{3}\right)$. Dengan harga $\mathrm{Rp} 100.000 / \mathrm{m}^{3}$, maka biaya yang dikeluarkan Rp 1.300.000/rumah. Biaya rata-rata yang dikeluarkan dalam satu kali pengambilan adalah Rp40.600 dan rata-rata dalam satu trip adalah $1 \mathrm{~m}^{3}$ maka rata-rata biaya yang dikeluarkan untuk $13 \mathrm{~m}^{3}$ adalah $\mathrm{Rp} 527.800$. Rumah permanen yang ada memiliki luas ratarata $48 \mathrm{~m}^{2}$ dan untuk konstruksi fondasi rumah tersebut dibutuhkan batu rata-rata $13 \mathrm{~m}^{3}$. Rumah permanen di desa menurut data potensi kelautan dan perikanan Kecamatan Pusomaen Desa Tumbak Tahun 2011 adalah 80 rumah. Karena kondisi keterbatasan lahan desa untuk membangun rumah, maka diasumsikan pertambahan rumah permanen per tahun $10 \%$ atau 8 rumah per tahun. Piperoleh, pemanfaatan yang telah terjadi untrik 80 rumah yakni $1.040 \mathrm{~m}^{3}$, dengan pertambahan / rata-rata $104 \mathrm{~m}^{3}$ per tahun. Manfaat langsung terumbu karang $\mathrm{Rp} 772.200 / \mathrm{KK}$ dan penambahan pemanfaatan terumbu karang bernilai Rp 6.177.600/tahun.

Persentase tutupan karang di depan desa dikategorikan rusak golopgan sedang. Masyarakat mengambil karâng untuk keperluan fondasi karena dianggaptelah rusak namun jika kegiatan ini terjadjterus-menerus, maka dapat diperkirakan lama-kelamaan akan hilang. Ekosistem terumbu karanng memiliki kemampuan yang baik dalam /memperbaiki diri sendiri bila terjadi kerusakan. Terumbu karang akan memperbaharui bagian yang rusak, dengan syarat kondisi lingkungannya terpelihara dengan baik, terumbu karang dapat kembali pulih tanpa campur tangan atau manipulasi langsung manusia (Dahuri, 1993). Pemanfaatan lainnya dari terumbu karang yang tidak dihitung yakni untuk tanggul, pembuatan jalan, resapan septic tank dan sebagainya yang tidak dihitung dalam penelitian ini. Tekanan yang ada mengakibatkan terumbu karang tidak dapat berfungsi secara ekologis sebagai penahan gelombang sehingga air laut dapat masuk sampai ke desa saat terjadi gelombang besar mengingat lokasi desa yang berupa daratan tanjung.

Total nilai manfaat langsung terumbu karang sebagai hasil tangkapan ikan karang dan bahan bangunan rumah diperoleh total nilai sebesar Rp4.866.177.600 (Tabel 1).

Tabel 1. Nilai Manfaat Langsung Terumbu Karang

\begin{tabular}{lc}
\hline \multicolumn{1}{c}{ Jenis Manfaat Langsung } & \multicolumn{1}{c}{$\begin{array}{c}\text { Nilai Manfaat } \\
\text { Langsung } \\
\text { (Rp/Tahun) }\end{array}$} \\
\hline $\begin{array}{l}\text { Nilai manfaat langsung penangkapan } \\
\text { ikan karang }\end{array}$ & 4.860 .000 .000 \\
$\begin{array}{l}\text { Nilai manfaat langsung konstruksi } \\
\text { bangunan pesisir (fondasi rumah) }\end{array}$ & 6.177 .600 \\
\hline \multicolumn{1}{c}{ Total } & $\mathbf{4 . 8 6 6 . 1 7 7 . 6 0 0}$ \\
\hline
\end{tabular}


Kegiatan pengambilan karang oleh masyarakat pesisir sebagai bahan bangunan sudah merupakan isu sejak lama (fondasi rumah, septic tank dan tanggul) serta untuk hiasan. Selain itu pemanfaatan terumbu karang yang menjadi penyebab rusaknya terumbu karang di Desa Tumbak juga karena pembuatan jalan perahu di daerah terumbu karang, pembuatan jangkar perahu, konstruksi budidaya rumput laut, pemasangan kurungan apung dan kurungan tancap. Kordi (2010) menyebutkan penduduk desa di pesisir Bacan Timur, Maluku Utara, mengambil karang untuk fondasi rumah dan bahan pembuatan kapur. Pembuatan kapur dengan menggunakan karang sudah berhenti sejak pertengahan tahun 1980, namun pengambilan karang untuk fondasi rumah masih terus berlangsung hingga saat ini.

Terumbu karang mengalami banyak tekanan sebagai akibat dari pola pemanfaatan yang tidak ramah lingkungan. Degradasi atau kerusakan ekosistem terumbu karang disebabkan oleh gangguan alami dan gangguan antropogenik seperti pengambilan karang, sedimentasi, limbah, eutrofikasi dan perikanan terumbu karang. Keindahan dan keunikan karang menyebabkan banyak mengkoleksinya sebagai hiasan dan hal ini akan menjadi serius bila tidak dilakukan pembatasan demikian pula dengan pengambilan batu karang untuk bahan bangunan (Tuwo, 2011).

Berdasarkan hasil dari 76 responden di peroleh informasi tentang kegiatan pengambilan karang yaitu 72 responden mempunyai pendapatan sampai dengan Rp 1.500.000/bulan (rata-rata Rp 1.217.763). Rata-rata jarak pengambilan karang sejauh 2,9 km dengan waktu tempu 3,6 jam/trip. Biaya yang dikeluarkan Rp 15.000-100.000 (ratarata $\mathrm{Rp} 40.500 /$ trip). Untak biaya membeli batu gunung yang diimpor dari desa tetangga dengan harga mengangkutnya sebesar $\mathrm{Rp} 100.000 / \mathrm{m}^{3}$ sehingga karang menjadî pilihan. Sarana jalan masuk dan keluar desa yang ada belum sepenuhnya baik menjadi salah satu faktor tingginya biaya angkutan. Dari hal-hal tersebut dapat dilihat alasan mengapa masyarakat pesisir di Desa Tumbak cenderung memanfaatkan potensi sumber daya terumbu karang.

Berdasarkan nilai persentase tutupan karang di perairan sekitar desa sebesar 31,8\%, nilai manfaat langsung penangkapan ikan karang diperoleh Rp4.860.000.000/tahun. Dengan asumsi jika pengambilan karang dihentikan dimana nilai manfaat yang diberikan dari aktivitas ini hanya Rp6.177.600/tahun kemudian karang dibiarkan memperbaiki kondisi ekosistem- nya tanpa ada tekanan antropogenik, diharapkan nilai manfaat langsung yang dapat diberikan oleh terumbu karang melalui penangkapan ikan karang bisa jauh lebih besar daripada yang diperoleh saat ini. Pendapatan masyarakat bisa bertambah karena produktivitas ikan meningkat dimana terumbu karang akan dapat menjalankan fungsi ekologisnya sebagai tempat pemijahan, tempat pengasuhan dan tempat mencari makan berbagai spesies ikan dan biota laut lainnya secara maksimal. Dengan demikian secara otomatis produksi sekunder (ikan dan bioto lautnya) di daerah terumbu karang akan meníngkat pula.

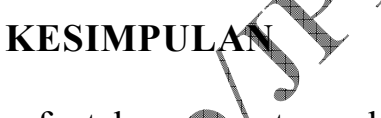

Nilai manfaat langsung terumbu karang adalah sebesar Rp 4.860.000.000/tahun dari kawasan penangkapan ikan karang, sedangkan nilai manfaat langsung sebagai bahan dasar fondasi rumah sebesar Rp 772.260/KK/dengan pertambahan sebesar $104 \mathrm{~m}^{3} /$ tahun, diperoleh nilai Rp 6.177.600,00/ tahun. Totat estimasi manfaat langsung adalah $\mathrm{Rp}$ 4.866.177600/tahun. Faktor utama yang mempengaruhr pemanfaatannya adalah biaya yang murah dan jarak yang dekat. Pemanfaatan terbanyak yakmi untuk pembuatan fondasi rumah. Praktik pemanfaatan yang tidak berkelanjutan ini menyebabkan degradasi kondisi terumbu karang sehingga persentasi tutupan karang hidup hanya 31,8\% termasuk dalam kategori rusak (sedang).

\section{UCAPAN TERIMA KASIH}

Tulisan ini merupakan bagian dari Tesis Program Magister Sains dari Penulis Pertama. Terima kasih kepada Dr. Ir. Adnan Wantasen, M.Si dan Dr. Ir. Edwin L.A. Ngangi, M.Si yang telah banyak membantu Penulis dalam menyelesaikan studi pada Program Pascasarjana Universitas Sam Ratulangi Manado; demikian pula kepada Kepala Desa Tumbak dan jajarannya atas kerjasamanya selama penelitian.

\section{DAFTAR PUSTAKA}

Bengen DG. 2002. Ekosistem dan Sumber daya Alam Pesisir dan Laut serta Prinsip Pengelolaannya. PK-SPL. IPB, Bogor.

Dahuri. 1993. Trend Kerusakan Sumber daya Wilayah Pesisir dan Lautan. Makalah Diskusi Pembangunan Lingkungan pada PELITA VI. Bappenas RI, Kantor Menteri Negara Lingkungan Hidup RI dan Lembaga Penelitian IPB. Bogor.

Data Potensi Kelautan dan Perikanan Kecamatan Pusomaen Desa Tumbak 2011. 
Dewi ES. 2006. Analisis Ekonomi Manfaat Ekosistem Terumbu Karang di Pulau Ternate Propinsi Maluku Utara. Program Pascasarjana Institut Pertanian Bogor.

Fauzi dan Anna. 2005. Pemodelan Sumber Daya Perikanan dan Kelautan. PT. Gramedia Pustaka Utama. Jakarta.

Kordi KMGH. 2010. Ekosistem Terumbu Karang. Rineka Cipta. Jakarta.

Keputusan Menteri Lingkungan Hidup Nomor 4 Tahun 2001 tentang Kriteria Baku Kerusakan Terumbu Karang.

Parizot Y. 2010. Empat Tahun Penelitian oleh Acroporis. Minahasa Tenggara.
Proyek Pesisir. 1999. Profil serta Rencana Pembangunan dan Pengelolaan Sumber Daya Wilayah Pesisir Desa Bentenan dan Desa Tumbak. Proyek Pesisir Sulawesi Utara dan BAPPEDA Kabupaten Minahasa.

Rembet UNWJ, Boer M, Bengen DG, Fahrudin A. 2011. Struktur Komunitas Ikan Target di Terumbu Karang Pulau Hogow dan Putus-Putus Sulawesi Utara. Jurnal Perikanan dan Kelautan Tropis VII (2): 60-65. Manado.

Supriharyono. 2004. Pengelolaan Ekosistem Terumbu Karang. Penerbit Djambatan, Jakarta.

Tuwo. 2011. Pengelolaan Ekowisata Pesisir dan Laut. Penerbit Brillian Internasional. Jakarta.

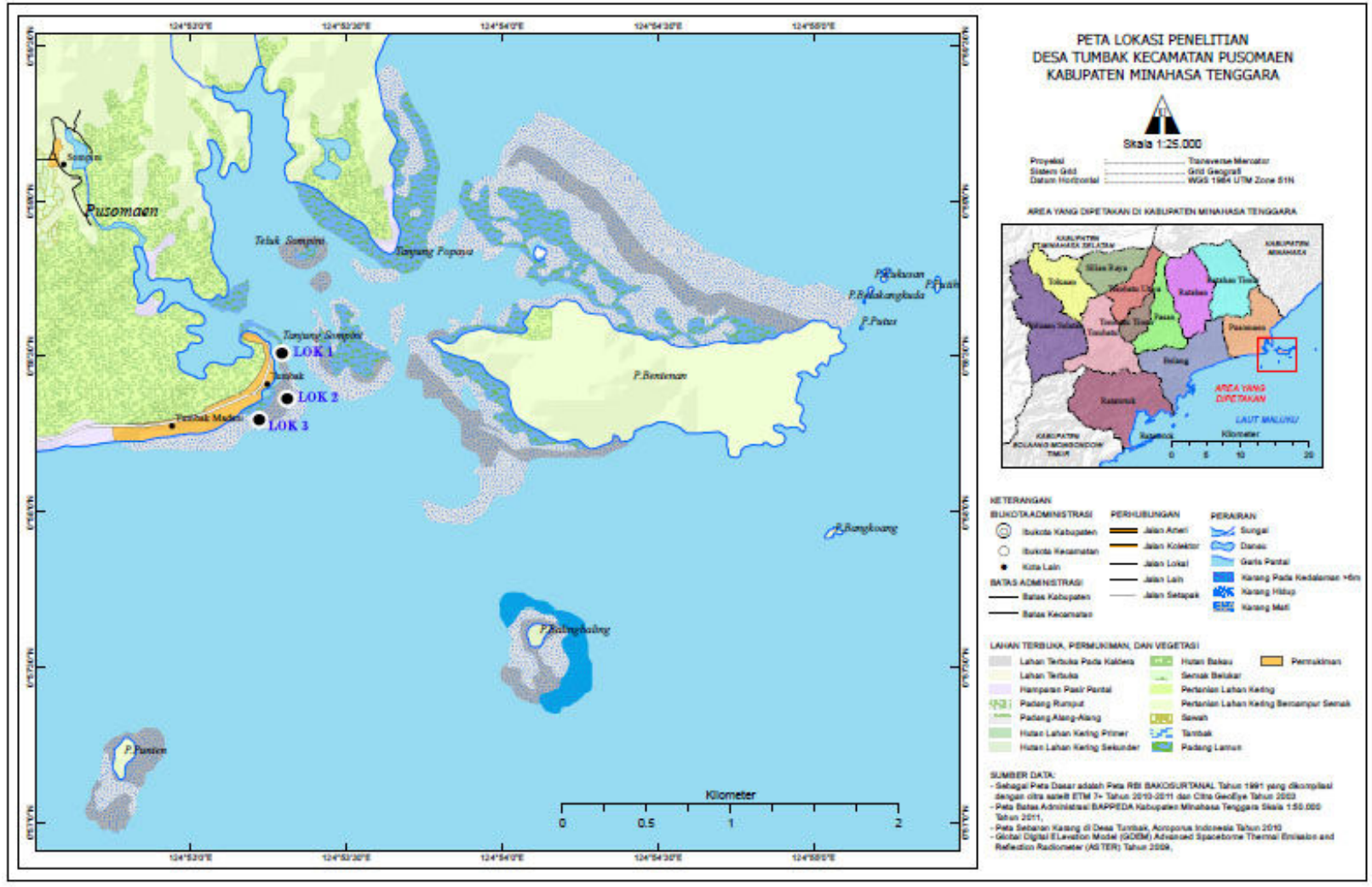

- Gambar peta kondisi karang pada lokasi penelitian.

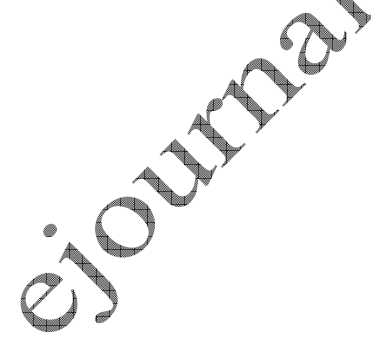

